A Poverty of Rights 



\section{A Poverty of Rights}

Citizenship and Inequality in

Twentieth-Century Rio de Janeiro

Brodwyn Fischer

$\approx$

STANFORD UNIVERSITY PRESS

STANFORD, CALIFORNIA

2008 
This book was published with the assistance of Northwestern University

\author{
Stanford University Press, \\ Stanford California \\ (C) 2008 by the Board of Trustees of the \\ Leland Stanford Junior University
}

No part of this book may be reproduced or transmitted in any form or by any means, electronic or mechanical, including photocopying and recording, or in any information storage or retrieval system without the prior written permission of Stanford University Press.

Library of Congress Cataloging-in-Publication Data

Fischer, Brodwyn M.

A poverty of rights : citizenship and inequality in twentieth-century Rio de Janeiro / Brodwyn Fischer.

p. $\mathrm{cm}$.

Includes bibliographical references and index.

ISBN 978-0-8047-5290-9 (cloth : alk. paper)

I. Poor-Civil rights-Brazil-Rio de Janeiro-History-2oth century. 2. Equality-Brazil—Rio de Janeiro-History—2oth century. 3. Rio de Janeiro (Brazil)—Politics and government—-2oth century. 4. Rio de Janeiro (Brazil)—Social conditions—2oth century. 5. BrazilPolitics and government—2oth century. I. Title.

HCI89.R4F $57 \quad 2008$

$323 \cdot 3^{\prime} 2942098$ I $53-\mathrm{dc2} 2$

200702542 I

Printed in the United States of America on acid-free, archival-quality paper

Typeset at Stanford University Press in Io/I 2 Sabon 
To My Family 
